\title{
Implications of Acts 1:8 for Ghanaian Neo-Pentecostal Missiology
}

\author{
Paul Kang-Ewala Diboro' ${ }^{1}$ (D) \& Boniface Kwaku Blewusi ${ }^{1}$ \\ 1 Department of Theology, Christian Service University College, Kumasi - Ghana.
}

\begin{abstract}
The book of Acts is often referred to by many scholars and preachers when discussing Christian missions with emphasis on Acts 1:8 as the centrality of the book. Unfortunately, very little exegetical study is done on the text by scholars in relation to missions. It appears that Luke fails to provide a detailed blueprint strategies or approaches to the command for missions (witnessing) in the text. This article therefore considers Acts 1:8 exegetically to establish its missionary importance. In the light of this, the article assesses the mission strategies of the Early Church, Historic Missions and Neo-Pentecostal/Charismatic Churches in Ghana. The article contends that, a reflection on the current trend of NeoPentecostal/Charismatic approaches or strategies to missions in Ghana gives a valuable insight of a departure from the early missionary strategies in general. The article acknowledges that, the recent widespread involvement of Pentecostal and Charismatic churches in the use of radio, social media, television, open-air crusades, street evangelism, preaching in buses, prayer and prophetic meetings/conventions, medical outreach work and social welfare are ways to fulfill missions in the light of Acts 1:8. The article also highlights the need to broaden the understanding and task of Christian missions to meet the challenges of the recent changing Ghanaian Christian religious landscape.
\end{abstract}

Keywords: Missions, Missiology, Neo-Pentecostal Churches, Early Church, Strategy, Book of Acts, Historic Churches.

\section{INTRODUCTION}

According to Hinne Wagenaar, "in the origin and development of African Theology, the Acts of the Apostles has been of considerable importance. African theologians refer often to passages from Acts. This may be related to the fact that African Christians identify easily with the missionary situation as described there. For him, the issues (traditional, cultural and political) the early Christian communities faced in the book are recognized by the African churches in their missiological contexts. ${ }^{1}$

The book of Acts plays an influential role in the beliefs and teachings of Pentecostal and Charismatic churches. It has influenced their theology, missiology, soteriology, ecclesiology, and pneumatology. ${ }^{2}$ No other New Testament book has records of early Christian missions in the Bible other than the Acts of the Apostles.

1 Hinne Wagenaar, "Stop Harassing the Gentiles: The Importance of Acts 15 for African Theology", Journal African Christian Thought, Vol. 6, No. 1 (June 2003): 44.

2 Francis Machingura, "A Contextual Analysis of Acts 2:1-13 and the Implications in The Apostolic Faith Mission in Zimbabwe (AFM)", From Text to Practice: The Role of the Bible in African Life Today, Bible in Africa Studies, edited by Masiiwa Ragies Gunda (Bamberg: University of Bamberg Press, 2011), 63. 
Present-day Christians who study the book of Acts with an open mind will discover that they are being challenged relative to what transpired in the Early Church. It is basically a book that details the inauguration of the church and its advancement to other people, tribes and nations.

There is substantial evidence from Christian history to suggest that Christian mission is over 2000 years now. This makes Christian mission a transition or movement, not an institution. John Mark Terry and J.D Payne argue that, "the church has two thousand years of missions history to draw from when it comes to understanding how the gospel spread and churches multiplied. Over the centuries numerous strategies have been used to advance the kingdom, with some working better than others". "It is a fact that Christian mission and its approach has changed drastically over the years beginning from the Early Church period, missionary era (early missionaries to Africa) to recent times. It is evident that the Pentecost narrative in Acts establishes the bases for the move in the Early Church's missionary agenda". ${ }^{4}$ Currently, it appears there is a paradigm shift in the approaches to missions from the early historic missions churches' perspectives to a more radical Pentecostal/Charismatic mission perspective. The early practices and approaches to missions from the historic/mission churches throughout the history of the church in Ghana and Africa at large were evident in the area of social interventions (schools, hospitals, agriculture and so on) in the communities in which these churches operate. But recently, it appears less attention is given to these perspectives among Neo-Pentecostals with an introduction of a new scientific approach to missions.

Christian mission is seen as a divine command to all Christian Churches (Matthew 28:18-20). But the understanding and approach to missions make it easier. It therefore involves the missionary activities of the body of Christ (church) in particular forms, mediums, channels, specific places, times, or needs of participation in mission also called missio dei which for Scott Sunquist is God's mission of saving the world or human beings taking part in this mission. ${ }^{5}$ Terry and Payne point out that for missions to yield the desired results it is important to have strategies. ${ }^{6}$ They define missionary strategy as the total set of procedures that depicts what is considered as what the Lord requires of mankind to do to make disciples amongst nations. ${ }^{7}$ For Edward Dayton and David Fraser, putting up a strategy for missionary endeavors is an effort to foresee what God wants to do in the future. ${ }^{8}$ In their view, it is a way of telling fellow Christians to understand and notice where to focus their efforts in missions. ${ }^{9}$ Against this backdrop, churches over the years and even in recent times have devised various strategies in their missionary quest to have the word of God propagated in every part of the country. By observation, the Pentecostal mission strategies in a way are a drift from the historic mission churches in Ghana. For Neo-Pentecostals, these new approaches or strategies are channels through which the preaching or witnessing task of Acts 1:8 could be better accomplished. Therefore, this article examines the missionary implications of Acts 1:8 in the light of the Early Church, Historic Mission Churches and particularly, Neo-Pentecostal Churches' mission strategies.

\section{METHODOLOGY}

This qualitative study adopted an exegetical approach to examine the text and other related literature resources for the study. An exegetical inquiry investigates a biblical text holistically. Conteh sees exegesis as a critical explanation or analysis, especially of a biblical passage. For him, "it is a thorough, analytical study of a biblical text, whose purpose is to arrive at an accurate useful interpretation". ${ }^{10}$ The exegetical approach

\footnotetext{
John Mark Terry and J.D. Payne, Developing a Strategy for Missions, A Biblical, Historical, and Cultural Introduction (Grand Rapids: Zondervan, 2013), 6.

4 Paul Kang-Ewala Diboro, "The Pentecost Event in Acts 2: Significance for Contemporary Christian Missions," E-Journal of Religious and Theological Studies Vol. 1, No. 2(2019): 108.

5 Scott W. Sunquist, Understanding Christian Mission: Participation in Suffering and Glory (Michigan, Grand Rapids: Zondervan, 2013), 7.

6 Terry and Payne, Developing a Strategy for Missions, A Biblical, Historical, and Cultural Introduction, 6.

7 Terry and Payne, Developing a Strategy for Missions, A Biblical, Historical, and Cultural Introduction, 6.

8 Edward R. Dayton and David A. Fraser, Planning Strategies for World Evangelization (Grand Rapids, Michigan: William B. Eerdmans Publishing Company, 1990), 14.

9 Dayton and Fraser, Planning Strategies for World Evangelization, 14.

10 Prince S. Conteh, An Exegesis of Paul's Use of Deisidaimon ("Religious") in Acts 17: A Handbook for Students and Pastors (Koforidua: Flash Image, 2012), 1.
} 
therefore seeks to address the question of "what did the author mean"? ${ }^{11}$ This exercise attempts to unravel the original intended meaning of the text or passage, that is, how the original recipients responded to it to make application thereof. The exegetical methods help to establish the context of the text at "then" and "now". For this study, this method is employed to examine the meaning and interpretation of Acts 1:8 and its implications for the current Pentecostal approach to missions in Ghana. The missiological implications of the text are discussed in the light of the diverse ways the Neo-Pentecostal churches understand and undertake missions currently. It is important to state that this study however does not seek to investigate into detail every aspect of Pentecostal churches and the Book of Acts in relation to Pentecostal missiology.

\section{DISCUSSIONS OF FINDINGS}

\section{The Missionary Importance of Acts 1:8}

Acts 1:8 explicitly sets out the mandate which symbolizes the motif for the entire book of Acts. Evidently, the text outlines the key theme of Acts and begins with the Spirit's empowering of the witness to Jesus. ${ }^{12}$ However, there is also a missiological significance for the book of Acts with Acts 1:8 as a central text. ${ }^{13}$ Despite the frequent use of Acts 1:8 in reference to the Holy Spirit and missions, few works have been observed. The disciples of Jesus Christ, having received the power of the Holy Spirit, "were now to be witnesses, and their definite work was to bear testimony to their Master, they were not to be theologians, or philosophers, leaders but witnesses. Whatever else they might become, everything was to be subordinate to the idea of personal testimony." 14

The verse (Acts 1:8) further indicates the exact assignment from Jesus Christ to his disciples, which is actually his final words prior to his ascension and thus is definitive. ${ }^{15}$ It was a commission with an assurance, and as such lays a responsibility on every Christian. It's about "a person, a power, and a program. The person by whose authority the church acts and who is the object of its witness; the power of the Holy Spirit, which is "sine qua non" for the mission; and a program that begins at Jerusalem, moves out to "all Judea and Samaria," and extends "to the ends of the earth." 16 This suggests that Acts 1:8 gives a road map for Christian missions with specifics, that is, the source, places and focus of missions. This holistic mission approach has been demonstrated by the apostles throughout the book of Acts. This missional program may suggest a church's independent theological distinctive approach to missions to convince or win others to embrace Christianity. From the above, mentioning Acts 1:8 gives a clear understanding of the apostles' assignment (witnessing), the message (Jesus Christ), the source of power to accomplish the assignment (the Holy Spirit), and the geographical landscape for missions. Of central importance to the apostles' assignment which though was not categorically stated in the text was how (methods/approaches/strategies to be employed) they were to undertake this mission program. This omission may suggest that the apostles and all those who were later involved in mission activities were not keeping to one missional program. As a result, there have been a fundamental shift in the understanding of missions and the strategies involved over the centuries.

\section{Exegetical Consideration of Acts 1:8 English Translation}

"But you shall receive power when the Holy Spirit has come upon you; and you shall be my witnesses in Jerusalem and in all Judea and Samaria and to the end of the earth" (Act 1:8 RSV)

\section{Transliterated Text}

Alla lémpsesthe dunamin epelthontos tou hagiou Pneumatos eph hymas kai esesthe mou martures en te lerousalẻm kai en pasẻ tẻ loudaia kai samareia kai heós eschatou tẻs gẻs

\footnotetext{
${ }^{11}$ Conteh, An Exegesis of Paul's Use of Deisidaimon ("Religious") in Acts 17, 1.

12 J.I. Packer, Wayne Grudem and Ajith Fernando, Global Study Bible: English Standard Edition (Illinois: Good News Publishers, 2001), 1524.

13 Diboro, "The Pentecost Event in Acts 2: Significance for Contemporary Christian Missions," 108.

14 W.H. Thomas Griffith, The Acts of the Apostles (London: Outline Studies in Primitive Christianity, 1986), 25-26.

${ }^{15}$ E. Frank Gaebelein, The Expositor's Bible Commentary (Michigan, Grand Rapids: Zondervan, 1981), 256.

16 Gaebelein, The Expositor's Bible Commentary, 256.
} 
The context for which the author places Acts 1:8 is crucial to the discussions. ${ }^{17}$ The text is part of Jesus' responses to his disciples in connection to the question about when the Kingdom would be restored to Israel. ${ }^{18}$ The author introduces his conclusions of the answer Jesus gave in reference to the disciples' question by drawing their attention to something relevant and needed for the restoration of the kingdom. The author does this with the expression, "But you will receive power when the Holy Spirit has come upon you"19, Alla lémpsesthe dunamin epelthontos tou hagiou Pneumatos eph hymas. By this expression, the author's intention is clear in pointing out what will precede the restoration of the kingdom of Israel. Ironside argues that while the disciples needn't know the time for the setting up of the kingdom, there was something equally vital for them to know. ${ }^{20}$

Alla (and) a conjunction in Greek has the sense of "but, instead, nevertheless, howbeit, notwithstanding, indeed, therefore". ${ }^{21}$ Used in the introduction of the text may suggest urgency and seeks to draw the attention of the disciples to something important being discussed. James Strong posits that alla as used by Luke in this text forms a transition to the cardinal matter. ${ }^{22}$ However, the view expressed by Strong does not suggest that the disciples' question was less important, but rather, it points the disciples to the issue that their master, Jesus regards as most crucial for them to know before he ascends to heaven. For Ajith Fernando, Luke used alla, to suggest that Jesus is giving another perspective which they needed most which is that instead of thinking about the physical restoration of Israel politically, they should focus on the power which they would receive through the Holy Spirit's baptism that will empower them to witness. ${ }^{23}$ Lémpsesthe is a protracted kind of a verb used only as a substitute in some types of tenses and also to indicate a future action and in the second person plural form translated as "you will receive". Its root word is lambano which means "I receive" or "I take" (probably objective or active, to get hold of). ${ }^{24}$ Luke used lempsesthe to give a view of when (in the future) and what the disciples are to receive, that is dunamin.

Dunamin (power) comes from the word dunamai translated as "to be able", "possible", "can" (do), "be of power", and "might" and the accusative singular form of dunamis is Dunamin, a feminine noun." 25 Luke uses this word 'dunamis' in a way that suggests that, the kind of power Jesus was referring to was unique and divine in nature; it is a supernatural and a special power to be received by the disciples to perform the special task of witnessing. For Strong, dunamis (power) is attributed to Jesus, and again the power to cure sicknesses comes from Christ, the kingly power of the Messiah is his, precisely the power to work signs and wonders (Acts 6:8; pasa dunamis). ${ }^{26}$ The Greek dunamis "appears ten times in Acts, sometimes referring to miracles or other effects of power (Acts 2:22; 3:12; 4:7; 8:13;10:38; 19:11) and other times to enablement". ${ }^{27}$

However, in the context of Acts 1:8, the power that the disciples are to receive is specifically for witnessing, doing missions. Bock notes that the spirit of God is connected to power dunamis that points to having been emboldened to declare courageously what God has done in the person of Christ. ${ }^{28}$ The disciples are to use the power they shall receive first and foremost for witnessing or missions.

epelthontos tou hagiou Pneumatos (when the Holy Spirit has come upon you) gives a clear understanding of where this power would be derived from. Epelthontos comes from the aorist verb eperchomai, in the singular neuter form which is translated as "to come upon" (that is; what comes and leaves its appropriate, inevitable effects that build on the particular coming) or "to arrive." ${ }^{29}$ Joseph Henry Thayer expands the meaning by

\footnotetext{
${ }_{17}$ Maurice A. Robinson, Fenton John Anthony Hort, Brooke Foss Westcott, Westcott and Hort Greek New Testament (1881) With Morphology (USA: Broadman, 1994), 6.

18 J.C. MacCaulay, Expository Commentary Acts (Chicago: Moody Press, 1978), 19.

19 ESV Global Study Bible (USA: Crossway, 2001), 1525.

${ }^{20}$ H.A. Ironside, Lectures on the Book of Acts (New York: Loizeaux Brothers, 1943), 21.

${ }^{21}$ James Strong, Strong's Exhaustive Concordance of the Bible (USA: Hendrickson Publishers, 2017), 1602.

22 Strong, Strong's Exhaustive Concordance of the Bible, 1602.

23 Ajith Fernando, The NIV the Application Commentary, from Biblical Text to Contemporary, (Michigan, Grand Rapids: Zondervan Publications, 1998),52.

24 Strong, Strong's Exhaustive Concordance of the Bible, 1644.

25 Strong, Strong's Exhaustive Concordance of the Bible, 1620.

26 Bible Hub. Acts: Expositor's Bible Commentary. accessed November 10, 2020 https://biblehub.com/greek/1411.htm

27 Darrell L. Bock, Acts, Baker Exegetical Commentary on the New Testament (Michigan, Grand Rapids: Zondervan, 2007$), 63$.

28 Bock, Acts, Baker Exegetical Commentary on the New Testament, 63.

29 Dirk Jongkind, The Greek New Testament (Illinois: Crossway, 2018), 281.
} 
translating it as, to "overtake." ${ }^{30}$ Joseph's translation may suggest the outwitting of a person in athletics in the mere understanding of the word but contextually, this may rather suggest an enduement, submersion, soaked in the Holy Spirit (tou hagiou Pneumatos). Luke may have carefully structured this verse to show the reader a sequence of how the disciples would receive the power, what to use the power for and the source of the power, tou hagiou Pneumatos, the Holy Spirit.

Hagiou Pneumatos (Holy Spirit) is a noun which is a combination of hagiou (an adjective which means holy) and Pneuma (a noun translated as Spirit but some versions use Ghost and this is because of the preference of translators). However, both hagiou and Pneumatos are in the genitive neuter singular form and Luke uses the phrase epelthontos tou (the) hagiou Pneumatos together with eph (a preposition which means upon) and hymas (second person plural in the accusative form and translated as 'you', properly referring to all the disciples of Jesus and not an individual disciple) to give a graphical presentation of how the disciples would receive the power of God and this is only "when the Holy Spirit has come upon them". For David J. Williams the statement alla lempsesthe dunamin epelthontos tou hagiou Pneumatos eph hymas (you shall receive Power when the Holy Spirit has come upon you) from the text must be seen as the effect of a cause. ${ }^{31}$ In his view, active evangelism could only emerge at the place of the Spirit (Pneuma), which is demonstrated in word, in actions and in the life of those who possess the Spirit. ${ }^{32}$ The way the Holy Spirit produces witnesses and strengthens them must be seen in the way the witnessing is done and this is well illustrated in Acts. ${ }^{33}$ For any witnessing or missionary activity to produce the necessary results, the presence and the power of the Holy Spirit is key.

Luke moves the focus in the verse from describing the sequence of what the disciples would receive, power through the Holy Spirit to pointing to what the disciples are to use the power for, thus kai esesthe mou martures en te lerousalém (and you will be my witnesses in Jerusalem).

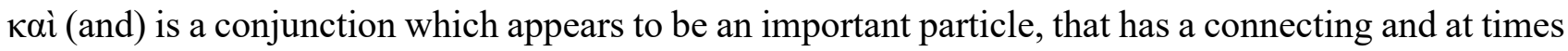
increasing strength translated as "and", "even", "so", "then", and frequently employed together with other words or particles. ${ }^{34}$ However in this verse kaì is translated as 'and' to show a connection between the power that the disciples would receive when the Holy Spirit comes on them and what they are to use the power for, that is witnessing. Lenski observes that Luke uses the conjunction "and" to suggest that what follows is the result of thus receiving power, and the future tense reads as though being witnesses is a continuation of the promise. This is not an admonition but only a glorious future fact hence esesthe mou martures (you will be my witnesses). ${ }^{35}$ Esesthe is a verb in the future indicative and second person plural form, which is translated as "you will be" and in this context points to the specific task the Lord had assigned to the disciples which is to be mou martures (my witnesses). For Marvin R. Vincent, the proper translation of mou is "of me" in the genitive form to show possessiveness. ${ }^{36}$ This presupposes that the Lord "owned" their lives and they are to live their lives to please Him alone and thus had a missionary assignment to undertake for him, to be "witnesses" (martures).

Martures comes from the word martus a masculine noun "of uncertain affinity; a witness (literally; judicially or figuratively; generally); by analogy a martyr, record, witness." ${ }^{37}$ Bock notes that Christ's reference to witnesses has a legal connotation (Matthew 18:16). He explains further that "a witness in this sense is someone who helps establish facts objectively through verifiable observation. As such, a witness is more than someone with merely subjective and personal impressions." "38 "Thus "witness" is a key term in Acts for those who experienced Jesus and saw him in a resurrection appearance (1:22). This experience means that they can testify directly to what God did through Jesus (Luke 24:48)." ${ }^{39}$ The witness in this context refers directly to the disciples of Jesus. However, over the period, it has assumed a general reference to the followers

30 Joseph Henry Thayer, Greek-English Lexicon of the New Testament (Grand Rapids, Michigan: Zondervan, 1975), 230.

31 David J Williams, Acts: Understanding the Bible Commentary Series (Michigan: Baker Publishing Group, 2011 ), 24.

32 Williams, Acts: Understanding the Bible Commentary Series, 24.

${ }_{33}$ Fernando, The NIV the Application Commentary, from Biblical Text to Contemporary, 52.

34 Strong, Strong's Exhaustive Concordance of the Bible, 1637.

35 Richard C. H. Lenski, The Interpretation of the Acts of the Apostles,(Columbus: The Wartburg Press, 1957$), 31$.

${ }_{36}$ Marvin R. Vincent, Word Studies in the New Testament (Grand Rapids, Michigan: Zondervan Publications, 1969$), 444$.

37 Strong, Strong's Exhaustive Concordance of the Bible, 1646.

38 Bock, Acts, Baker Exegetical Commentary on the New Testament, 64.

39 Bock, Acts, Baker Exegetical Commentary on the New Testament, 64. 
of Jesus Christ. Hence, the disciples of Jesus moved from town to town, province to province and empire to empire with the good news of Jesus Christ being emboldened by the Holy Spirit. This explains why Peter could boldly exclaim in Acts 4:20 that "we cannot help speaking about what we have seen and heard" (ESV) because they were witnesses to the life and ministry of Jesus.

In the context of Acts 1:8, the disciples are to start this witnessing work "in Jerusalem, and in all Judea and Samaria, and to the end of the Earth" 40 translated in Greek as ". Lerousalém kai en pasé té loudaia kai samareia kai heós eschatou tés gés" ( in Jerusalem and in all Judea and Samaria and to the end of the earth). ${ }^{41}$ Luke uses en (preposition which means "in"), tẻ (a conjunction which means "both"), pasẻ (an adjective in the dative case in a feminine singular which means "all"), and te (an article in the dative case and a feminine singular which is translated as "the") ${ }^{42}$ to provide a geographical view of the areas they are instructed by Jesus Christ to start their world evangelization task. In line with this, Bock observes that the witness will begin "in Jerusalem", from there move to "Judea and Samaria" then "to the end of the earth" (kai heós eschatou tés gés). And this is so because a cursory look at what pertains in the Book of Acts presents Jerusalem as key in Acts chapter one to chapter seven, Judea and Samaria had issues in chapter eight to chapter ten. Then shortly a return was made to Jerusalem in chapter eleven to chapter twelve, the word of God propagated with key attention given to the Antioch mission lastly getting to Rome via Paul. ${ }^{43} \mathrm{He}$ further explains that in this sense Acts 1:8 introduces the book by showing a concern for the geographical positioning of these towns that Luke loves to note. ${ }^{44}$ Geography in the context of Acts 1:8 is important particularly taking into consideration the relevance of these three towns (Jerusalem, Judea and Samaria) in the unfolding history of Israel.

In the words of J. Alexander, the reference to Jerusalem and all Judea does not just pertain to the capital, just as some may expect, but rather throughout the country. And the use of pasé (all) to qualify Loudaia perhaps represents the whole of that jurisdiction besides the capital, or Judea in the broader understanding as meaning all the country. ${ }^{45}$ Alexander further explains that the mention of Samareia the final, is not prohibited, whose dwellers were not recognized as Jews (seen in Jhn 4:9), however, is presented at this point as a kind of nonaligned area in the middle of Jews and Gentiles. ${ }^{46} \mathrm{In}$ his view, this broad understanding is preferred by the situation that Galilee is not mentioned, even though many have expressed the opinion that it is named in the final words as "the uttermost part of the land." 47

However, some scholars express the view that the last phrase, heós eschatou tés gés (to the end of the earth) is ambiguous. ${ }^{48}$ For instance, Yon Gyong Kwon points out that the phrase could be explained with three different meanings; the end of the inhabited world (geographically), Paul's arrival in Rome (politically, 28:16), or the conversion of the Gentiles (racially, 10.1-11.8) (9) $^{4}$ but for Williams, the phrase had taken on a wider meaning within the period Luke was writing Acts, embracing the Roman Empire, epitomized by Rome itself, and on that basis, Luke adopted the program of this verse as a framework for his narrative. ${ }^{50}$ Alexander also thinks that "unto" as used by Bible Versions like the KJV is not a full representation of the preposition in Greek 'heós' that may be explained in English in reinforced forms like "out to," "even to," "as far as," all suggesting a notion of a farther stretch. ${ }^{51}$ However, as Christians, it is important to understand this phrase from a broader view of world missions.

\section{Summary of the Discussion}

According to Packer, Grudem and Fernando, Acts 1:8 is what forms the framework for the move of God

\footnotetext{
${ }^{40}$ ESV Global Study Bible (USA: Crossway, 2001), 1525.

41 A. H. Anthony, Westcott, Foss, Westcott and Hort Greek New Testament (1881) With Morphology, 10.

42 Strong, Strong's Exhaustive Concordance of the Bible, 1646.

43 Bock, Acts, Baker Exegetical Commentary on the New Testament, 64.

${ }^{44}$ Bock, Acts, Baker Exegetical Commentary on the New Testament, 64.

45 J. A Alexander, A Commentary of the Acts of the Apostles (Edinburgh: Morrison and Gibb, 1980), 12.

46 Alexander, A Commentary of the Acts of the Apostles, 12.

47 Alexander, A Commentary of the Acts of the Apostles, 12.

48 Yon Gyong Kwon, A Commentary on Acts: Society for Promoting Christian Knowledge (London: SCM Press, 2012 ), 8.

49 Gyong Kwon, A Commentary on Acts, 8.

50 Williams, Understanding the Bible Commentary, 24.

51 Alexander, A Commentary of the Acts of the Apostles, 12.
} 
through the Holy Spirit in witnessing the risen Christ to the world. ${ }^{52}$ The verse gives a description of what the Lord requires of his disciples giving a preview of what the early church must be doing after his ascension. Darrell L. Bock submits that "the verse emphasizes the part played by the disciples who are witnesses in the Book and the work of God stands at the core of the accounts that follow, narrating God's activity in establishing the church through Jesus's activity." ${ }^{53}$ Therefore Acts 1:8 appears to be the strategic verse in the New Testament for missions. It points out the power behind Christian missions and the geographical locations as well as the people to reach out to. Unfortunately, the methods for embarking on Christian missions were not indicated in the verse. In view of this, Christian missions do not remain at the level of the preaching of the gospel even though it's the central aim. It also considers the social wellbeing of the people who are the recipients of the gospel. Acts 1:8 is therefore an important verse as it gives a forecast of what Christian missions entail.

The role that the Holy Spirit plays in missions is imperative for the success or failure of any missionary venture. Fernando suggests that Acts as a Book can be described as the "Acts of the Holy Spirit" because whatever is achieved by the church is done via the Spirit of God. ${ }^{4}$ Peter White and Cornelius J.P Niemandt also argue that from the Pentecostal standpoint, the part the Holy Spirit plays is crucial to the mission of God. ${ }^{55}$ Therefore missions come from God himself as the father, to Jesus Christ his Son, then through the Holy Spirit. The Holy Spirit then empowers the church to take the mission of God to the entire universe. ${ }^{56}$ It is only when the Holy Spirit is involved in this missionary endeavor, that God's salvific plan can be effected. Charles $\mathrm{K}$. Barret attests to the fact that the power that comes from the Spirit is first and foremost for witnessing. It is to help them bear oral testimony, work miracles and act with authority. ${ }^{57}$ Similarly, David E. Pratte affirms that the "purpose of the power was not to prove to the one who had it that he had been saved, but to enable him to preach the message to others and to confirm to others that the message was from God so the hearers could believe the message and be saved." 58 Thus, it is obvious that, without the Holy Spirit, missions or witnessing will remain an exercise in futility, all done in the energy of the flesh and with no or little results to show. The article now examines the early church's evangelistic strategies.

\section{Early Church Missions/Evangelistic Strategies}

According to the Book of Acts $(2: 46,6: 4)$, the apostles focused on prayer, the ministry or preaching of the word of God and breaking of bread at their homes. In discussing the missionary methods of the Early Church, the observation of Fanning Don is relevant here. He noted that:

Now that they were free to do so, there was much preaching in public. Those who understood the gospel now faced an extremely difficult task of assuring the genuine conversion of the new multitudes. Every opportunity for conversations about Christ was exploited. As the new reality set in, many sought opportunities to teach in schools, and develop training schools for presbyters and other church leaders. Using their homes, without buildings, the congregations divided into cells. This simple methodology was beginning to disappear as soon as the huge Cathedrals became available to the Christians. Soon every church had to model the prestigious Cathedrals. ${ }^{59}$

Don further observes the important role oral witnessing, personal testimonies, literacy and word-of-mouth sharing of the gospel contributed to the spread and growth of the Church in the early Christian ministry. He

\footnotetext{
52 Packer, Grudem and Fernando, Global Study Bible: English Standard Edition, 1524.

53 Bock, Acts, Baker Exegetical Commentary on the New Testament, 2.

54 Fernando, Acts, the NIV Application Commentary 52.

55 Peter White and Cornelius J.P Niemandt, The Missional Role of the Holy Spirit: Ghanaian Pentecostals'View and Practice, 49(1), (2015), accessed online on June 12, 2020, from http://dx.doi.org/10.4102/ids.v49i1.1987.

56 Van Gailyn Rheneen, "Missio Dei” A Journal of Missional Theology and Praxis, accessed online on November 12, 2018, https://missiodeijournal.com/issues/md-1/authors/md-1-van-rheenen

${ }^{57}$ Charles K. Barret, "A Critical and Exegetical Commentary on the Acts of the Apostles", Vol. 1 The International Critical Commentary Series (Edinburgh: T \& T Clark, 1994): 1-9.

58 David E. Pratte, Commentary on the Book of Acts: Bible Study Notes and Comments (Michigan, Grand Rapids: Zondervan, 2013), 24.

59 Fanning Don, "Brief History of Methods and Trends of Missions", Trends and Issues in Missions. 1. (2009): 5, accessed November 10, 2020, https://digitalcommons.liberty.edu/cgm_missions/1
} 
argues that, "the gospel spread mostly through oral witnessing, personal testimonies and word-of-mouth sharing of personal faith. Literacy was scarce, especially on the fringe of the Empire". He claims "the Church Fathers, for instance, utilized their only means of communication: writing literature especially on evangelism, apologies, letters, and polemic discussions of the time." Similarly, he notes that much time was spent by these Church Fathers in reproducing Scriptures as the only means of increasing the number of the texts in biblical languages (Greek, Hebrew) and mostly Latin. ${ }^{60}$ Don further discloses that public testimony by conduct, trials, or martyrdom of many Christian as well as the leaders before the Edict of Tolerance was an observable phenomenon in the Early Church. A notable public testimony Don mentioned was the early believers' commitment and dedication to show how they love Christ through social service. According to him, Harnack "lists 10 different ministries from supporting widows and orphans, to helping prisoners and slaves that characterized the early Christians." ${ }^{61}$ It appears the historic missions to Ghana share some similar approaches to missions with the above views.

\section{The Context and Significance of Historic Mission Churches Strategies in Ghana}

The presence of European Christians in Ghana dates back to the $15^{\text {th }}$ Century when the Portuguese arrived in the then Gold Coast specifically Shama. However, by the $19^{\text {th }}$ Century, it was difficult to trace any evidence of Christianity in the country. ${ }^{62}$ Subsequently, other missionary bodies followed with the Roman Catholic Church missionaries arriving at Elmina in 1880 represented by two products of Society of Africa Missions (SMA), Father Eugene Morat and Augustus Morean. ${ }^{63}$ Hitherto, the two missionaries with the Moravian United Brethren Mission, Christian Protten and Henrich Huckuff had arrived in the Gold Coast and were actively engaged in the evangelization of the natives in the 1730s ${ }^{64}$ Basel Mission also started its missionary work in Ghana with Andreas Riis going to Akropong in the Akuapem Mountains in 1832 and in the same year January, the Wesleyan Methodist missionary work began in Ghana with the arrival of Dunwell Joseph at Cape Coast, ${ }^{65}$ and many other missionaries followed later on.

It is important to state that most of these early European Christian missionaries who came to Ghana had or adopted some strategies in their quest to get the gospel to the natives. When the first Portuguese came with the missionaries, some of the missionary strategies they used included exchanging Christianity for trade benefits also known as 'requerimiento,' the outright condemnation of everything African also known as 'Tabula Rasa,' and some others which certain scholars point to as faulty missionary strategies. ${ }^{66}$ Due to these strategies that were employed, the missions achieve little or no result.

Subsequently, some missionary groups employed other missionary strategies in order to win the people over to Christ. The Basel missionaries for example built a mission station, chapel and a school wherever they went to. Education was one of the strategic missionary priorities of the early European Christian Missionaries. ${ }^{67}$ This was very important for the acceptance and the spread of the gospel in that, the people were been educated together with being taught the word of God by the Chaplains. ${ }^{68}$ Jones Amanor again notes that another strategy used by the missionaries was linguistics studies. He explains that language became a barrier for transmitting the gospel, for attempts were made to scientifically analyze the native language so that they could literary express themselves. Soon, the Bible was translated into Twi and Ga. ${ }^{69}$ Paul Diboro, citing the work of Abadamloora and Gilleece on the strategies adopted by the Roman Catholic who worked amongst the Dagaaba also notes that the provision of clinics and drinking water by the missionaries proved that the gospel message was practically translated. He further noted that the treatment of diseases by the clinics resulted in

\footnotetext{
${ }^{60}$ Don, "Brief History of Methods and Trends of Missions", 6.

${ }^{61}$ Don, "Brief History of Methods and Trends of Missions", 6.

62 Jones Darkwa Amanor, Pentecostalism in Ghana: An African Reformation, accessed online on September 10, 2021, from http:// www.pctii.org/cyberj/cyberj13/amanor.html

${ }_{63}$ Amanor, Pentecostalism in Ghana, 4.

${ }^{64}$ Amanor, Pentecostalism in Ghana, 5.

${ }^{65}$ Amanor, Pentecostalism in Ghana, 5-6.

66 Samuel B. Adubufuor, Church History: Survey (Kumasi: Christian Service University College, 1995), 26.

${ }^{67}$ Amanor, Pentecostalism in Ghana, 8.

${ }^{68}$ Amanor, Pentecostalism in Ghana, 8.

${ }^{69}$ Amanor, Pentecostalism in Ghana, 9.
} 
the massive response to the new faith by the people..$^{70}$ In addition to the above, the missionaries also trained and employed some of the natives to be "Pastoral agents and co-evangelizers" 71 which helped the indigenes to wholly embrace the gospel; they better related with their own people. Amanor affirms that "these efforts are pivotal for the spread of the gospel". ${ }^{72}$ These and many other strategies were employed by the early European Christian missionaries. In recent times both the Pentecostal and neo-Pentecostal churches are relentless in their effort to get the gospel across to as many people as they can, and to do this, they have appropriated various scientific approaches to achieve this. Before assessing these scientific missional approaches, is a discussion on Pentecostal missiology or theology.

\section{Understanding Pentecostal Mission Theology/Missiology}

To understand Pentecostalism is to understand Pentecostal theology. Without a doubt, Neo-Pentecostalism is an offshoot of Pentecostalism. Pentecostalism is one of the renewal movements of the twentieth Century which currently has been noted by some scholars as one of the mainline churches in Ghana. ${ }^{73}$ Diboro argues that Pentecostalism is linked up to the Pentecost event in Acts. He observes that:

Pentecostal and Charismatic (Pentecostalism) movements, in general, are undoubtedly traced to the happenings on the day of Pentecost in Acts. Accordingly, Pentecostalism took inspiration from the Pentecost event in Acts which seems to have marked the beginning of the Christian movement or mission. This means that Pentecostalism is as old as the Church. ... perhaps from the day of Pentecost. It is without a doubt that some of their beliefs and emphasis are linked with wider developments and understanding of the happenings of the day of Pentecost. It is possible, therefore, to suggest that, theologically, the root of Pentecostal and Charismatic churches and even certain Charismatic movements or spiritual groups in the mainline churches is embedded in the contemporary understanding of the Pentecost in Acts. ${ }^{74}$

\section{According to Asamoah-Gyadu,}

Pentecostalism refers to Christian groups which emphasize salvation as a transformative experience wrought by the Holy Spirit and in which pneumatic phenomena including 'speaking in tongues', prophecies, visions, healing and miracles in general, perceived as standing in historic continuity with the experiences of the early church as found especially in the Acts of the Apostles, are sought, accepted, valued, and consciously encouraged among members as signifying the presence of God and experience of His Spirit. ${ }^{75}$

Subsequently, as time progressed, Pentecostalism in Ghana started gaining some level of grounds as strands of these churches began springing up as offshoots of this movement called the Neo-Pentecostal/Charismatic churches. Presently, Pentecostalism represents an important, prevailing and clear evidence of religious renewal and influence in Ghana. ${ }^{76} \mathrm{~A}$ critical and fair analysis of Ghana's religious narrative will show that Pentecostalism appears to have gained firm ground with the Neo-Pentecostal churches arguably pushing, this movement to another pitch in most recent times.

The Neo-Pentecostal movement is seen as a new brand of Christianity that seems to be enjoying massive growth and influence in Ghana at the moment because of its distinctive nature and approach to missions and ministry. Asamoah Gyadu indicates that:

The neo-Pentecostal movement has a theological distinctiveness that points to believing in the enabling power of God following the experience of His Holy Spirit. One implication of this pneumatic experience is that individual Christians are given what participants often express as "a ministry" or an enabling power, and spiritual sensitivity which is not necessarily imparted through

\footnotetext{
70 Paul Kang-Ewala, "The Dagaaba with the Christian Faith: Missiological Implications for the Church in the Dagaaba Land”, Ghana Journal of Religion and Theology, volume 8.1 (2018): 119.

${ }^{71}$ Diboro, "The Dagaaba with the Christian Faith", 119.

72 Amanor, Pentecostalism in Ghana, 9.

${ }^{73}$ Kwabena Asamoah-Gyadu, African Charismatics: Current Developments Within independent Indigenous Pentecostalism in Ghana (Netherlands: African Christian Press, 2005), 12.

74 Diboro, "The Pentecost Event in Acts 2: Significance for Contemporary Christian Missions", 104.

75 Asamoah-Gyadu, African Charismatics, 12.

${ }^{76}$ Asamoah-Gyadu, African Charismatics, 14.
} 
ecclesiastical rites and ceremonies. Such ministry or spiritual power, participants testify, is granted through a confirmable experiential encounter with the Holy Spirit. ${ }^{77}$

In essence, Neo-Pentecostalism is exclusively experiential in character. Perhaps, this may explain why it is centered on personalities. The theological emphasis of the relevance of the work of the Holy Spirit and Power in Christian missions is a common phenomenon in Neo-Pentecostal/Charismatic churches. On the Ghanaian religious landscape, the Neo-Pentecostal/Charismatic churches have made great waves, and have subsequently put in place what appears to be a scientific missionary strategy which enables them to spread the gospel across all sections of the Ghanaian society.

\section{Current Strategies of Neo-Pentecostal Churches to Missions}

In the words of Malphurs Audrey, "the strategy of the church is the vehicle that enables the church to accomplish her mission or overall goal, which is the great commission." 78 In his view missions are to be accomplished through a strategy. Much so, without a missionary strategy, the church and its evangelistic groups will be wasting their time..$^{79}$ Narrowing this understanding of missions in Ghana in contemporary times, White and Niemandt observes that "A study of the mission documents of Ghanaian Pentecostal churches, especially those of the classical Pentecostals as well as some neoPentecostal churches, show that they have well-planned strategies for missions" ${ }^{\circ 0}$ which they claim are empowered and guided by the Holy Spirit. For the neo-Pentecostals, these strategies are to help them fulfill biblical promises through the power of the Holy Spirit. ${ }^{81}$ It is observed that, to some extent, both historic and Pentecostal/Charismatic Churches share common mission approaches. But attention is recently drawn to the uniqueness of Pentecostal/Charismatic churches involvement in rigorous missions highlighting a number of strategies such as the electronic media and missions, spreading the gospel through social media, the social welfare approach, open air crusades, evangelism on the street, preaching in the buses, prayer and prophetic meetings/conventions, worship concerts and medical outreach for spreading the gospel.

\section{Open Air Crusades}

Crusades are one of the major contemporary Ghanaian missionary strategies. Crusades are one of the greatest components of church missions and are more so the most attended by local residents. ${ }^{82}$ Organising a gospel crusade is a concentrated effort to evangelize a city, village or town ${ }^{83}$ According to White and Niedmant, a lot of Pentecostal (including neo-Pentecostal) churches in Ghana put together unique mass evangelism programs often two times a year, particularly during Easter and Christmas periods. These mass crusades are sometimes referred to as conventions. ${ }^{84}$ They further note that, the central focus of most of these mass crusades is the spreading of the gospel of Jesus Christ often supported by miracles, deliverance and healings and followed by testimonies. It's also to "strengthen the one-on-one evangelism" and establish churches where there are none ${ }^{85}$ under the power and direction of the Holy Spirit. For some neo-Pentecostal Pastors, crusades are the right platform to demonstrate the power of God received through the Holy Spirit (Acts 1:8) to the world. White and Niedmant point out that the general belief of Ghanaian Neo-Pentecostals is that the coming of the Holy Spirit brings the power to perform 'signs and wonders' through the name of Jesus Christ to approve the gospel being preached. ${ }^{86}$ For Anderson, "The role of 'signs and wonders', particularly those of healing and miracles,

77 Asamoah-Gyadu, African Charismatics, 27.

78 Aubrey Malphurs, Strategy 2000: Churches Making Disciples for the Next Millennium (Grand Rapids: Kregel Resources, 1996), 30.

79 Peter White and J. P. Niemandt, “Ghanaian Pentecostal Churches' Mission Approaches”, Journal of Pentecostal Theology 24(2015): 244.

${ }^{80}$ White and Niedmant, Ghanaian Pentecostal Churches' Mission Approaches, 244.

${ }^{81}$ Kwabena Asamoah-Gyadu, Sighs and Signs of the Spirit: Ghanaian Perspectives on Pentecostalism and Renewal in Africa (London: Regnum Books International, 2015), 17.

${ }^{82}$ Benard Lango, Method: How to Execute a Church Mission and Evangelism Project (Kenya: Jomo Kenyatta University of Agriculture and Technology, 2019), 4.

83 "Is a Gospel Crusade a Biblical Method of Evangelism?," Got Questions Ministries, accessed February 15, 2020, https://www.gotquestions.org/is-a-gospel-crusade-a-biblical-method-of-evangelism.html

${ }^{84}$ White and Niemandt, Ghanaian Pentecostal Churches'Mission Approaches, 250.

${ }^{85}$ White and Niemandt, Ghanaian Pentecostal Churches'Mission Approaches, 250.

${ }^{86}$ White and Niemandt, Ghanaian Pentecostal Churches' Mission Approaches, 250. 
is prominent in the Pentecostal mission praxis. Pentecostals see the role of healing as good news for the poor and afflicted", ${ }^{87}$ and it's an effective medium of winning people into the kingdom of God. One of the NeoPentecostal churches that has actively appropriated this strategy is the Lighthouse Chapel International with its 'Healing Jesus Crusade'. "In 2008, at Wenchi, witches testified of their deliverance and many Muslims got healed and 516,941 decisions were made to follow Christ." 88

\section{Evangelism on the Street/Bus}

Street evangelism is the act of evangelizing the religious faith and in this case Christianity and has been associated with the neo-Pentecostal Churches. ${ }^{89}$ Some of these churches move on the street with placards, some of which reads "Repent, Jesus is coming soon", "Heaven and Hell is real", "Jesus Christ is the only way to God", "tomorrow may be too late, accept Jesus now", "Jesus loves you" and many others. While some display these placards, others will also be sharing evangelistic tracts to moving crowd and others also engage in person to person evangelism, ${ }^{90}$ with the view that the Holy Spirit is able to use these means to bring people into the Kingdom of God which basically affirms what is pointed out in Acts 1:8. Covenant Outreach ministries, a neo-Pentecostal church in Ghana, observed that at one of their street evangelism in Dixcove in the western region, 400 tracts were shared and 121 persons gave their lives to Christ through the power of the Holy Spirit. ${ }^{91}$ Many more neo-Pentecostal churches in recent times are still employing this means to share the gospel with people under the influence of the Holy Spirit in their quest to fulfill the great commission. But recently, the outbreak and spread of COVID-19 has adversely affected this missional approach of Pentecostals and Charismatics to Christian missions in Ghana and the world at large.

\section{Spreading the Gospel through Electronic and Social Media}

The advent of information and communication technology did not only benefit the secular world, but also the church and, for that matter, mission and evangelism. ${ }^{92}$ The Media, both electronic and social have become effective channels for some Neo-Pentecostal churches in reaching a wider audience. They include radio, television and social media; Facebook, Twitter, WhatsApp, Instagram and many others. In the wake of COVID 19, radio, television and Facebook have become the virtual church room and pulpit through which many church services are transmitted to congregants of these neo-Pentecostal churches. Some mainline and classical Pentecostal churches such as The Church of Pentecost and Assemblies of God are actively using these media channels to share the word which hitherto was not the case. Brawner writes, 'if the church is to effectively reach this sight and sound generation for Christ, we must utilize the same media roads much more than what the society is using every day. ${ }^{93}$

\section{The Radio Strategy}

In Ghana, it has become normal for a church to own a local radio station and for a pastor to be called a radio pastor. For some, the radio has become their church and pulpit. The use of the radio has been one of the strategic means of spreading the gospel particularly in Ghana and was first started by Rev. James Kessler of the Assemblies of God in 1968 with a radio ministry, known as 'Bible Time', which was aired on Ghana Broadcasting Cooperation. ${ }^{94}$ More so, in the 1970s the Church of Pentecost began its radio ministry dubbed

87 Allan Anderson, Towards a Pentecostal Missiology for the Majority World. Azusa Street and Beyond (Florida: Bridge-Logos, 2006), 4.

${ }^{88}$ In the year 2006 the healing Jesus crusades moved to. Accessed on July $8^{\text {th }}, 2020$ https://www.coursehero.com/file/p21ouqe/Inthe-year-2006-The-Healing-Jesus-Crusades-moved-to-Adisadel-College-Cape/

${ }^{89}$ Outreach to Infuma - June 24, 2020.https://covenantmessenger.org/outreach-to-infuma-june-24-2020/ published on 30 ${ }^{\text {th }}$ June, 2020. Accessed on July $8^{\text {th }}, 2020$.

90 Available on https://covenantmessenger.org/outreach-to-infuma-june-24-2020/ published on 30 ${ }^{\text {th }}$ June, 2020. Accessed on July $8^{\text {th }}, 2020$.

${ }^{91}$ Outreach to Infuma - June 24, 2020.https://covenantmessenger.org/outreach-to-infuma-june-24-2020/ published on 30 ${ }^{\text {th }}$ June, 2020. Accessed on July $8^{\text {th }}, 2020$.

92 M. Pocock, G. Van Rheenen, and D. McConnell, The Changing Face of Missions: Engaging Contemporary Issues and Trends (Grand Rapids, MI: Baker Books, 2005), 299.

93 Jeff Brawner, 'Meeting and Using the Media', in T.E. Trask, W.I. Goodall, and Z.J. Bicket (eds.), The Pentecostal Pastor: A Mandate for the $21^{\text {st }}$ Century (Springfield, MO: Gospel Publishing House, 1997), 369.

94 Available online: http://www.agghana.org/hq/gh/index.php/aboutus [Accessed 26 June, 2013 ]. 
'The Pentecost Hour' which was broadcast on Ghana Broadcasting Cooperation Radio 2 with the aim of reaching out to people with the gospel. ${ }^{95}$ However, in recent times, some of the Neo-Pentecostal Churches have taken radio preaching to another level with the claim that it is aided by the power of the Holy Spirit. Stan Chu Ilo observes that neo-Pentecostal churches are now visible in Ghana's media landscape, running radio and television stations. ${ }^{96}$ For him, the power of God is demonstrable in the preaching of the gospel and the working of miracles on the radio. A lot more people have been touched by the Holy Spirit through the radio ministry. Some of them have a 'media ministry' in the church that is dedicated to the production, sales and transmission of radio and/or TV programs, audio and/or videotapes and CDs, and PR material such as TV commercials. Some have their own well-equipped media production studio and media teams who are professionals in that field. ${ }^{97}$ For example, Altar Media is the name of the media department of Mensa Otabil's International Central Gospel Church (ICGC), one of Ghana's largest and most influential neo-Pentecostal/ Charismatic churches. ${ }^{98}$ Dr. Mensah Otabil has his preaching messages aired every weekday on Joy FM at 12:35pm dubbed "The Living Word'. Bishop Dag Heward Mills has his messages played and sometimes broadcasted live on Sweet Melodies FM (owned by Lighthouse Chapel International) every day often titled the "The Mechaniah". These messages are often referred to as anointed messages, whose sources are the Holy Spirit. Usually, after preaching, they invite listeners who are not born again to do so which epitomizes the essence of missions. Radio is one of the churches' strategies for achieving missions and evangelism. ${ }^{99}$ Many people have in one way or the other testified about how God saved, healed, delivered, empowered and worked a miracle in their life through the preaching of the gospel on the radio, which is often asserted by the neoPentecostals as backed by the power of the Holy Spirit.

However, White and Niemandt note that, a lot of the current generation of NeoPentecostal churches use this medium to advertise themselves as in "how powerful they are" to enhance their material and financial fortunes. ${ }^{100}$ Rather than using the power they purport to have received for preaching the word of God, they use the media to boost the charisma of the leader and manage his public personality, thus turning pastors into media celebrities. ${ }^{101}$ Some even use the radio as a medium to share numbers of various lottery platforms which they claim to have received from God. White and Niemandt further observe that some of these pastors use the radio as a channel to insult fellow pastors as well as their critics, and an example is a current rift between Rev. Ebenezer Opambour of the Ebenezer Miracle Worship Center, Kumasi and Bishop Daniel Obinim of the God's Way International Church, also in Kumasi. ${ }^{102}$ Nonetheless, it is important to state that there are some of these Neo-Pentecostal Pastors who are focused on the use of the radio to propagate the gospel of Jesus Christ through the power of the Holy Spirit to a wider audience all across the country.

\section{Televangelism Strategy}

Televangelism is the use of television for evangelistic activities. ${ }^{103}$ According to Asamoah Gyadu, "it is a term derived from the word television and evangelism." 104 Televangelism refers to deliberate efforts by religious organizations and interests to buy airtime for the purpose of mediating their activities to the public for very specific ends, including the "winning of souls." "105 Televised church services and radio programs have become increasingly abundant in the Ghanaian media. In contemporary Ghana, there are a number of Christian

${ }_{95}$ The Church of Pentecost, Pentecost Fire and Hour Report in December, 1974 annual report, 29. COP Archives, Accra.

${ }_{96}$ Stan Chu Ilo, Pentecostalism, Catholicism, and the Spirit in the World (Orlando: Wipf and Stock Publishers, 2019), 256.

${ }^{97}$ Marleen De-Witte, Business of the Spirit: Ghanaian Broadcast Media and the Commercial Exploitation of Pentecostalism (Netherlands: University of Amsterdam, 2011), 195.

${ }_{98}$ De-Witte, Business of the Spirit, 196.

${ }^{99}$ Peter White and Abraham Assimeng, "Televangelism: A study of the 'Pentecost Hour' of the Church of Pentecost", HTS Teologiese Studies / Theological Studies. 72. (2016), 10.4102/hts.v72i3.3337.

${ }^{100}$ White and Niemandt, Ghanaian Pentecostal Churches'Mission Approaches, 256.

${ }^{101}$ M. De Witte, 'Altar Media's Living Word: Televised Charismatic Christianity in Ghana', Journal of Religion in Africa, 33: 2 , (2003): 172-202.

${ }^{102}$ White and Niemandt, Ghanaian Pentecostal Churches'Mission Approaches, 256.

${ }^{103}$ Britannica, The Editors of Encyclopaedia. "televangelism". Encyclopedia Britannica, 1 Jul. 2019, https://www.britannica.com/topic/televangelism. Accessed 10 November 2021

104 J.K. Asamoah-Gyadu, 'Get on the Internet!' says the Lord: Religion, Cyberspace and Christianity in Contemporary Africa', Studies in World Christianity, 13(3), (2007): 241-242.

${ }^{105}$ Asamoah-Gyadu, 'Get on the Internet!' says the Lord, 241-242. 
televised church services on various television channels, particularly by Pentecostal churches, ${ }^{106}$ including the neo-Pentecostal churches. Neo-Pentecostal churches have over the period used television as a medium to spread the gospel, with a great upsurge in recent times in Ghana which was not the case some twenty years back. ${ }^{107}$ Some two decades ago among the neo-Pentecostal churches, Mensah Otabil's 'Living Word', Duncan William's 'Voice of Inspiration', Heward Mills' 'Mega Word', Agyin Asare's 'Miracle Encounter', Sam Korankye's 'Power in His Presence', Isaac Anto's 'Let the Prophet Speak', Christie Doe Tetteh's 'Solid Rock', and Gordon Kisseih's 'Treasures of Wisdom' were often aired either on TV3, GTV and Metro TV. ${ }^{108}$ However, currently, many more neo-Pentecostal churches have their own satellite TV stations, including some of the pioneering ministries aforementioned. A few that can be mentioned include Dominion TV of Action Chapel, Precious TV of Perez Chapel, OB TV of the International God's Way International, Power TV of Royal House Chapel and many others. These TV stations are often used to spread the gospel, to demonstrate the power of God by healing the sick and the working of miracles; which are some essential features of the neo-Pentecostal churches in Ghana. Neo Pentecostals/Charismatics emphasize that these "signs and wonders" should accompany the preaching of the Word in evangelism, and divine healing, in particular, is an indispensable part of their evangelistic methodology, ${ }^{109}$ under the move and the power of the Holy Spirit. For them, the power promised in Acts 1:8, was not only for witnessing but also for the working of miracles without losing sight of the main purpose of the presence of the Spirit power for the former. Their extensive broadcasting activity attracts broad audiences far beyond their membership and influences not only other Christian denominations but also non-Christian religions ${ }^{110}$ and the public. ${ }^{111}$ On live television, cripples are seen walking, the blind begin to see, the deaf begin to hear and many more miracles are performed with the assertion that they have been touched by the power of the Holy Spirit. The use of the television has become one of the effective missionary approaches that these churches use to draw people to their churches, thereby leading to the growth of the church.

Yet, some Pastors of certain neo-Pentecostal Churches in recent times appear to be using the medium of television to promote themselves rather than the gospel. ${ }^{112}$ De-Witte opines that some of these churches "in making effective use of media to boost the charisma of their leader and manage his public personality, a new religious format has come to revolve around charismatic media personalities, thus turning pastors into full-fledged media celebrities with strong similarities to 'secular' stardom." 113 Francis Benyah also observes that many of these neo-Pentecostal churches have commercialized religious substances like the anointing oil and other products such as handkerchiefs, soaps, car stickers, etc. and charge excessive prices even beyond its market value, thereby making the church some sort of business enterprise. These items are claimed to bring favor and deliverance through the power of the Holy Spirit. ${ }^{114}$ These practices that have engulfed television broadcasts in recent times appear to be washing away the gains that are made by the few who are focused on spreading the gospel through television.

\section{Facebook/ Instagram Strategy}

According to Peter White et al, The Internet World Statistic Report of 2015 indicates that, as of $30^{\text {th }}$ November, Ghanaian subscribers on Facebook were about 2,900,000 people, representing 1.6\% of the population. He observes that, among the mobile internet users in 2015, Facebook was ranked the most used social media

\footnotetext{
${ }^{106}$ White and Assimeng, "Televangelism: A study of the 'Pentecost Hour' of the Church of Pentecost”, 10.4102/hts.v72i3.3337.

${ }^{107}$ De-Witte, Business of the Spirit, 193.

${ }^{108}$ Paul Gifford, "Ghana's New Christianity: Pentecostalism in a Globalizing African Economy. Nova Religion", The Journal of Alternative and Emergent Religions 9. (2006): 31.

${ }^{109}$ Willem A. Saayman, 'Some reflections on the development of the Pentecostal mission model in South Africa', Missionalia 21(1), (1993): 46.

${ }^{110}$ Marleen De-Witte, 'The Spectacular and the Spirits: Charismatics and Neo-Traditionalists on Ghanaian Television', Material Religion 1(3), (2005): 314-35.

${ }^{111}$ Marleen De-Witte, 'Business of the Spirit: Ghanaian Broadcast Media and the Commercial Exploitation of Pentecostalism, Journal of African Media Studies 3/2 (2011), 189-205; Meyer, American Ethnologist.

${ }^{112}$ White and Niemandt, Ghanaian Pentecostal Churches' Mission Approaches, 256.

${ }^{113}$ Marleen De-Witte, Television and the Gospel of Entertainment in Ghana (Netherlands: Brill, 2012), 150.

${ }^{114}$ Francis Benyah, Commodification of the gospel and the socio-economics of neo-Pentecostal/Charismatic Christianity in Ghana, Accessed online on July 6, 2020, from https://dx.doi.org/10.4314/ljh.v29i2.5
} 
platform in Ghana with $94.89 \% .{ }^{115}$ Statistics regarding the use of Facebook by Ghanaian pastors indicate that in July through to October 2015, Pastor Mensa Otabil's (the General overseer of the International Central Gospel Church) Facebook page was the fastest-growing page in Ghana, with about 149 users every day, 8,516 weekly and 28,607 in a month. ${ }^{116}$ White's report demonstrates that by August 19, 2015, among the top 30 Facebook users in Ghana, Pastor Mensa Otabil came ninth (9th) with 902,209 followers, Bishop Dag HewardMills in the tenth (10th) position, with 742,739 followers. Archbishop Nicolas Duncan-Williams was the twelfth (12th) on the list with 673, 807 followers and Pastor Richard C. Witcomb in the twenty-second (22nd) position with 422, 017 followers. ${ }^{117}$ It is important to state that the current statistics of the use of Facebook by these pastors might have gone up considerably.

It is to be noticed from the above statistics that the churches in Ghana with the most followers on Facebook in Ghana are the Neo-Pentecostal Pastors. ${ }^{118}$ This proves how Facebook has given these pastors and their churches an additional opportunity to communicate with a larger number of people, spread the gospel and disciple their followers through this medium, even more currently during this COVID-19 period. 'Social media ministry and for that matter, the Facebook ministry has brought about what could be referred to as a "church without walls." ${ }^{119}$ White notes that when some of the followers of Pastor Mensa Otabil, Bishop Dag Heward-Mills, Archbishop Nicolas Duncan Williams were engaged on how they profited from the Internet activities of these pastors, they pointed out that 'the Facebook ministry has broken all geographical barriers and protocols that hitherto hindered preaching and the hearing of the gospel'. They further noted that Facebook has brought a transformation in their lives as they are drawn closer to God regardless of where they are, through the power of God. ${ }^{120}$

Whilst it is an established reality that some Neo-Pentecostal pastors use Facebook to promote themselves and their churches, sell anointing oil, stickers, handkerchiefs, some others are also using this same electronic platform for missional purposes with the help and power of the Holy Spirit. For example 'Bishop Dag Heward-Mills of Lighthouse Chapel International and Bishop Charles Agyin Asare of Perez Chapel International have successfully used this approach for their crusades and church planting activities'. ${ }^{121}$

\section{Prayer and Prophetic Meetings/Conventions Strategy}

Prayer and Prophetic meetings are some of the most common strategies that some Neo-Pentecostal/ Charismatic churches use as an evangelistic/missionary strategy to draw people to God. Prayer forms an important aspect of the Ghanaian concept of Christianity. This is affirmed by McQuilkin who postulates that 'prayer is the human conduit of divine energy for mission'. ${ }^{122}$ Many Neo-Pentecostal/Charismatics often organize prayer and prophetic meetings with the aim of spreading the gospel. They often publicize some of these upcoming events by using posters, handbills, and other images on the television. ${ }^{123}$ What characterizes these meetings are fervent prayers, deliverance sessions, prophecies and many more which is often asserted to be a demonstration of the power of the Holy Spirit expressed in Acts 1:8. Meyer points out that the "prayer service attracts a large number of people, most of whom are members of other churches, yet feel drawn to this powerful event, in the course of which pastors promise 'showers of blessings' that materialize in health, wealth, visa and other much wanted matters" 124 For these churches, it is the Holy Spirit that gives them the power to fervently pray against all activities of 'abeyiefoc' (witches) who are behind their misfortunes. They

\footnotetext{
${ }^{115}$ P. White, F. Tella, \& M.D. Ampofo, “A missional study of the use of social media (Facebook) by some Ghanaian Pentecostal Pastors". KOERS - Bulletin for Christian Scholarship, 81. 2(2016). Available at: http://dx.doi.org/10.19108/ koers.81.2.2250

${ }^{116}$ White, Tella, \& Ampofo, "A missional study of the use of social media (Facebook) by some Ghanaian Pentecostal Pastors". KOERS - Bulletin for Christian Scholarship, 81. 2(2016). Available at: http://dx.doi.org/10.19108/ koers.81.2.2250, 4.

${ }^{117}$ White, Tella, \& Ampofo, "A missional study of the use of social media (Facebook) by some Ghanaian Pentecostal Pastors", 4.

${ }^{118}$ White, Tella, \& Ampofo, "A missional study of the use of social media (Facebook) by some Ghanaian Pentecostal Pastors", 4.

${ }^{119}$ White, Tella, \& Ampofo, "A missional study of the use of social media (Facebook) by some Ghanaian Pentecostal Pastors", 4.

${ }^{120}$ White, Tella, \& Ampofo, "A missional study of the use of social media (Facebook) by some Ghanaian Pentecostal Pastors", 5.

${ }^{121}$ White, Tella, \& Ampofo., "A missional study of the use of social media (Facebook) by some Ghanaian Pentecostal Pastors", 5.

${ }^{122}$ Robertson J. McQuilkin, 'The Role of the Holy Spirit in Mission', in Douglas C. McConnell (ed.), The Holy Spirit in Mission

Dynamics (Pasadena, CA: William Carey, 1997), 31.

${ }^{123}$ Asamoah-Gyadu, Sighs and Sighs of the Spirit, 76.

${ }^{124}$ Birgit Meyer, Pentecostal and Neo-Liberal Capitalism: Faith, Prosperity and Vision in African Pentecostal-Charismatic Churches (New York: Palgrave, 2007), 28.
} 
also give 'sumsum akwakyere' (Spiritual directions) and perform miracles. Asamoah-Gyadu points out that for Ghanaian Neo-Pentecostals, spiritual experience gives room for the reception of ministry gifts of the spirit which includes healing, discernment and prophecy. ${ }^{125}$ One of the pioneering prayer meetings in the neo-Pentecostal realm is Action Chapel's "Jericho Hour", which takes place every Thursday at the Prayer Cathedral in Accra. At "Jericho Hour", there is fervent prayer, worship songs and prophecies delivered to individuals. Before the meeting ends there is an altar call where people who have not made the decision to follow Christ are given that opportunity.

However, Aboagye Aryeh notes that some of these Neo-Pentecostal/Charismatic Christians "who claim to have been endowed with the gift of prophecy by the Holy Spirit, largely use it to attract and entice other Christians to leave their denominations to join them. Using prophecy to convert non-Christian is virtually absent." 126 This notwithstanding, the effect of this evangelistic/missionary strategy cannot be underestimated in contemporary neo-Pentecostal/Charismatic missiology.

\section{Medical Outreach Strategy}

Medical outreach is also an effective means of reaching people with the gospel and some neo-Pentecostal/ Charismatic churches have adopted this strategy in their determination to spread the gospel of Jesus Christ. Medical outreach is a missionary strategy that targets primarily the needy and vulnerable in communities or in society by sharing the love of Christ through medical aid. ${ }^{127}$ Some Neo-Pentecostal and Charismatic churches have been actively involved in this outreach program. Notable amongst them is the Lighthouse Chapel International. This outreach program is called 'The Healing Jesus Medical Missions Outreach'. According to Rachel Pauline Aikins Mawuko, the medical outreach is geared towards providing free healthcare to less deprived communities in Ghana and their surrounding neighbors in the bid to spreading the love of Christ, ${ }^{128}$ which is central to the gospel of Jesus Christ. In her view, medical outreach is a demonstration of what the gospel entails, that is helping the helpless under the guidance of the Holy Spirit. A lot more people have been saved through the medical outreach program. 'While the medical team took care of the people's medical needs, another group from the team shared the Word of God with the people. When the Gospel was preached, close to two hundred of the beneficiaries gave their lives to Christ while many others were encouraged in their Christian walk'. ${ }^{129}$ Dag Heward Mills, a medical doctor himself believes that in doing so, the door to share the gospel of Christ and to win souls for the kingdom of God is opened. ${ }^{130}$ For these churches, it is the Holy Spirit that is working through this medium to save souls.

\section{Social Welfare Strategy}

Over the years, the church as a whole has contributed immensely to the socio-economic development of Ghana. The building of schools, hospitals, or clinics, the provision of potable drinking water for a range of communities in need of such services were the key strategies of the early missionaries. Social work is the professional activity of helping individuals, groups or communities to enhance or restore their capacity for social functioning and creating societal conditions favorable to its goal, ${ }^{131}$ and in the view of the NeoPentecostal Churches, it takes the guidance of the Holy Spirit to get it done. As part of their social responsibility programs, these churches have social and outreach ministries that give various forms of assistance to the communities in which they operate.

\footnotetext{
${ }^{125}$ Asamoah-Gyadu, African Charismatics, 27.

${ }^{126}$ Daniel Aboagye Aryeh, Assessing the Role of Prophecy in mission in Charismatic Christianity in Ghana: An Exegesis of 1 Corinthians 14:24-25 (Accra: Missiological Society of Ghana, 2018), 161.

${ }^{127}$ Medical Missions Outreach, Pointing others to the great Physician, accessed online on July 3, 2020, from https://www.medical-outreach.com.

${ }^{128}$ Rachel Pauline Aikins Mawuko, "Name It, Claim It, Grab It" The Hermeneutical Approach of Lighthouse Chapel International (Legon: University of Ghana, 2016), 82.

${ }^{129}$ Hundreds Benefit from Medical Outreach, available on https://www.theovision.org/2015/11/11/hundreds-benefit-from-medical-out//, accessed on $4^{\text {th }}$ July, 2020.

${ }^{130}$ In the year 2006 the healing Jesus crusades moved to. Accessed on July $8^{\text {th }}, 20204$ https://www.coursehero.com/file/p21 ouqe/In-the-year-2006-The-Healing-Jesus-Crusades-moved-to-Adisadel-College-Cape/

${ }^{131}$ National Association of Social Workers, Standards for Social Service Manpower, 4(4) (Washington: The Association, 1973), accessed online on 10 November 2021 from https://www.socialworkers.org/Search-Results?search=\%E2\%80\%9C
} 
Action Chapel International, for example, has a department called Compassion in Action (C.I.A). It is in charge of the church's social and outreach ministry. It focuses primarily on six areas, which include; helping orphanages and providing rehabilitation centers. ${ }^{132}$ Selly Gharbin observes that the Single Mothers and Widows Ministry also assists single mothers who have difficulties in taking care of their children, and widows who are financially incapacitated. ${ }^{133}$ In addition to this, some are given food, clothes, shelter and in some communities, social amenities like potable water, clinics, schools are provided. In the case of C.I.A., over two hundred scholarships worth over GHC114, 000 have been given to brilliant but needy students. ${ }^{134}$ As to whether these activities lead to soul winning, Amos Jimmy Markin tells that various results were achieved and hundreds of people came to accept Christ. ${ }^{135}$ This is a fulfillment of the missionary task of the church relative to Acts 1:8. Social welfare evangelism continues to be one of the effective means through which the gospel is spread by some neo-Pentecostal churches in Ghana.

\section{RECOMMENDATION}

Considering the focus of the study, this article recommends that, Neo-Pentecostal churches in Ghana should be encouraged to seek technical and financial support from groups and individuals who desire to promote this contemporary pattern approach to missions. Some of these approaches (preaching in buses and crusades) noted above need to be improved upon particularly in this COVID-19 era. It is also important to enforce a regulatory system to ensure monitoring and evaluation of how these Neo-Pentecostal churches use the media. A balanced approach to missions is relevant i.e. the Early Church, historic churches and Neo-Pentecostal approaches. This will make the Christian attitude towards missions in the Ghanaian context holistic and comprehensive. It is also important for Ghanaian Christian churches to see the need to broaden the understanding and task of Christian missions to meet the challenges of the recently changing Ghanaian Christian religious landscape.

\section{CONCLUSION}

In summary, it has become evident that missions in the Book of Acts was initiated, empowered by the Holy Spirit and undertaken by the apostles and later adopted by the churches and individuals that followed. It has also been observed that the role and portrayal of their missions' strategies have changed over the periods and present some challenges and possibilities for the church today. For certain reasons, as far as Neo-Pentecostals are concerned in this context, the approach to Neo-Pentecostal missiology is a holistic task which finds expression in the context of Acts 1:8. For many Neo-Pentecostals, the use of these current approaches or technologies (social media, radio, television, Facebook, street evangelism and so on) is another empowered opportunity by the Holy Spirit to fulfill the Great Commission of Jesus Christ to the Church on missions in these last days.

\section{ABOUT AUTHORS}

Paul Kang-Ewala Diboro is a Lecturer, Department of Theology, Christian Service University College, Kumasi Ghana. He is also the Pastor of Church Obuasi, Ghana.

Boniface Kwaku Blewusi - Department of Theology, Christian Service University College, Kumasi - Ghana.

\section{BIBLIOGRAPHY}

Aboagye Aryeh, Daniel. Assessing the Role of Prophecy in mission in Charismatic Christianity in Ghana: An Exegesis of 1 Corinthians 14:24-25. Accra: Missiological Society of Ghana, 2018.

\footnotetext{
132 Godibert Kelly Gharbin, Solitude in a Multitude: An Intercultural Reading of John 5:1-47 (Legon: University of Ghana, 2016), 80.

${ }^{133}$ Gharbin, Solitude in a Multitude: An Intercultural Reading of John 5:1-47, 82.

${ }^{134}$ Gharbin, Solitude in a Multitude: An Intercultural Reading of John 5:1-47, 81.

${ }^{135}$ Amos Jimmy Markin, Transmitting the Spirit in Missions: the History and Growth of the Church of Pentecost (Orlando: Wipf and Stock, 2019), 137.
} 
Adubufuor, Samuel B. Church History: Survey. Kumasi: Christian Service University College, 1995.

Aikins, Mawuko Rachel P. "Name It, Claim It, Grab It" The Hermeneutical Approach of Lighthouse Chapel International. Legon: University of Ghana, 2016.

Amanor, Jones D. Pentecostalism in Ghana: An African Reformation. Accessed on September 10, 2021, from http://www.pctii.org/cyberj/cyberj13/amanor.pdf

Anderson, Allan. "Towards a Pentecostal Missiology for the Majority World." In Azusa Street and Beyond, edited by Gramt McClung. Florida: Bridge-Logos, 2006.

Alexander, J. A. A Commentary of the Acts of the Apostles. Edinburgh: Morrison and Gibb, 1980.

Asamoah-Gyadu, J.K. "'Get on the Internet!' says the Lord: Religion, Cyberspace and Christianity in Contemporary Africa,"” Studies in World Christianity, 13(3), (2007).

Asamoah-Gyadu, Kwabena. African Charismatics: Current Developments Within independent Indigenous Pentecostalism in Ghana. Netherlands: African Christian Press, 2005.

Asamoah-Gyadu, Kwabena. Sighs and Signs of the Spirit: Ghanaian Perspectives on Pentecostalism and Renewal in Africa. London: Regnum Books International, 2015.

Robinson, M. A., M. Anthony H. F. J. Foss, W. B. Westcott and Hort Greek New Testament (1881) With Morphology. USA: Broadman, 1994.

Barret, C.K. "A Critical and Exegetical Commentary on the Acts of the Apostles", Vol. 1 The International Critical Commentary Series. Edinburgh: T\&T Clark, 1994.

Benyah, Francis. Commodification of the gospel and the socio-economics of neo-Pentecostal/Charismatic Christianity in Ghana. Accessed online on July 6, 2020, from https://dx.doi.org/10.4314/ljh.v29i2.5

Bible Hub. Acts: Expositor's Bible Commentary. https://biblehub.com/greek/1411.htm

Birgit, Meyer. Meyer, Pentecostal and Neo-Liberal Capitalism: Faith, Prosperity and Vision in African Pentecostal-Charismatic Churches. New York: Palgrave, 2007.

Bock, Darrell L. Acts, Baker Exegetical Commentary on the New Testament. Michigan, Grand Rapids: Zondervan, 2007.

Brawner, Jeff. 'Meeting and Using the Media.' In The Pentecostal Pastor: A Mandate for the $21^{\text {st }}$ Century, edited by T.E. Trask, W.I. Goodall, and Z.J. Bicket. Springfield, MO: Gospel Publishing House, 1997.

Britannica, The Editors of Encyclopaedia. “televangelism”. Encyclopedia Britannica, 1 Jul. 2019, https://www.britannica.com/topic/televangelism. Accessed 10 November 2021

Campbell, H. \& P. Calderon. The Question of Christian Community Online: The Case of the Artist World Network', Studies in World Christianity 13(3), (2007): 261-277.

Chu Ilo, Stan. Pentecostalism, Catholicism, and the Spirit in the World. Orlando: Wipf and Stock Publishers, 2019.

Conteh, Prince S. An Exegesis of Paul's Use of Deisidaimon ("Religious") in Acts 17: A Handbook for Students and Pastors. Koforidua: Flash Image, 2012.

Dayton, Edward R. and David A. Fraser. Planning Strategies for World Evangelization. Grand Rapids, Michigan: William B. Eerdmans Publishing Company, 1990.

De Witte, M. 'Altar Media's Living Word: Televised Charismatic Christianity in Ghana', Journal of Religion in Africa, 33(2), (2003).

De-Witte, Marleen. 'Business of the Spirit: Ghanaian Broadcast Media and the Commercial Exploitation of Pentecostalism, Journal of African Media Studies 3/2 (2011), 189-205.

De-Witte, Marleen. 'The Spectacular and the Spirits: Charismatics and Neo-Traditionalists on Ghanaian Television', Material Religion, 1(3), (2005).

De-Witte, Marleen. Business of the Spirit: Ghanaian Broadcast Media and the Commercial Exploitation of Pentecostalism. Netherlands: University of Amsterdam, 2011.

De-Witte, Marleen. Television and the Gospel of Entertainment in Ghana. Netherlands: Brill, 2012.

Diboro, Kang-Ewala, Paul. “The Pentecost Event in Acts 2: Significance for Contemporary Christian Missions," E-Journal of Religious and Theological Studies, Vol. 1(2), (2019).

Diboro, Kang-Ewala, Paul. "The Dagaaba with the Christian Faith: Missiological Implications for the Church in the Dagaaba Land", Ghana Journal of Religion and Theology, volume 8.1 (2018). 
Don, Fanning. "Brief History of Methods and Trends of Missions", Trends and Issues in Missions. 1. (2009):

5. Accessed online on November 10, 2020, from https://digitalcommons.liberty.edu/cgm_missions/1.

ESV Global Study Bible. USA: Crossway, 2001.

Fernando, Ajith. Acts, the NIV Application Commentary. Michigan, Grand Rapids: Zondervan Publications, 1998.

Gaebelein, E. Frank. The Expositor's Bible Commentary. Michigan, Grand Rapids: Zondervan, 1981.

Gharbin, Godibert Kelly. Solitude in a Multitude: An Intercultural Reading of John 5:1-47. Legon: University of Ghana, 2016.

Gifford, Paul. "Ghana's New Christianity: Pentecostalism in a Globalizing African Economy.

Griffith, W.H. Thomas. The Acts of the Apostles. London: Outline Studies in Primitive Christianity, 1986.

Hundreds Benefit from Medical Outreach, available on https://www.theovision.org/2015/11/11/hundredsbenefit-from-medical-out/, accessed on $4^{\text {th }}$ July, 2020.

Ironside, A. H. Lectures on the Book of Acts. New York: Loizeaux Brothers, 1943.

Jongkind, Dirk. The Greek New Testament. Illinois: Crossway, 2018.

Kwon, Yon Gyong. A Commentary on Acts: Society for Promoting Christian Knowledge. London: SCM Press, 2012.

Lango, Benard. Method: How to Execute a Church Mission and Evangelism Project. Kenya: Jomo Kenyatta University of Agriculture and Technology, 2019.

Lenski, R. C. H. The Interpretation of the Acts of the Apostles. Columbus: The Wartburg Press, 1957.

MacCaulay, J.C. Expository Commentary Acts. Chicago: Moody Press, 1978.

Machingura, Francis. "A Contextual Analysis of Acts 2:1-13 and the Implications in The Apostolic Faith Mission in Zimbabwe (AFM)", From Text to Practice: The Role of the Bible in African Life Today, Bible in Africa Studies, edited by Masiiwa Ragies Gunda. Bamberg: University of Bamberg Press, 2011.

Malphurs, Aubrey. Strategy 2000: Churches Making Disciples for the Next Millennium. Grand Rapids: Kregel Resources, 1996.

Markin, Amos Jimmy. Transmitting the Spirit in Missions: the History and Growth of the Church of Pentecost. Orlando: Wipf and Stock, 2019.

Medical Missions Outreach, Pointing others to the great Physician, accessed online on July 3, 2020, from https://www.medical-outreach.com.

McQuilkin, Robertson J. 'The Role of the Holy Spirit in Mission.' In The Holy Spirit in Mission Dynamics, edited by Douglas C. McConnell. Pasadena, CA: William Carey, 1997.

National Association of Social Workers, Standards for Social Service Manpower.(Washington: The Association, 1973), accessed online on $10^{\text {th }}$ November 2021 from

https://www.socialworkers.org/Search-Results?search=\%E2\%80\%9C

Nova Religion", The Journal of Alternative and Emergent Religion, 9, (2006).

Outreach to Infuma - June 24, 2020.https://covenantmessenger.org/outreach-to-infuma-june-24-2020/ published on $30^{\text {th }}$ June, 2020. Accessed on July $8^{\text {th }}, 2020$

Packer, J.I., Wayne Grudem and Ajith Fernando. Global Study Bible: English Standard Edition. Illinois: Good News Publishers, 2001.

Pocock, M., G. Van Rheenen, and D. McConnell. The Changing Face of Missions: Engaging Contemporary Issues and Trends. Grand Rapids, MI: Baker Books, 2005.

Pratte, David E. Commentary on the Book of Acts: Bible Study Notes and Comments. Michigan, Grand Rapids: Zondervan, 2013.

Rheneen, Van Gailyn. "Missio Dei”, A Journal of Missional Theology and Praxis. Accessed on November 12, 2018, from https://missiodeijournal.com/issues/md-1/authors/md-1-van-rheenen

Saayman, Willem A. 'Some reflections on the development of the Pentecostal mission model in South Africa', Missionalia 21(1), (1993).

Strong, James. Strong's Exhaustive Concordance of the Bible. USA: Hendrickson Publishers, 2017.

Sunquist, Scott W. Understanding Christian Mission: Participation in Suffering and Glory. Michigan, Grand Rapids: Zondervan, 2013. 
Terry, John Mark and Payne J.D,. Developing a Strategy for Missions, A Biblical, Historical, and Cultural Introduction. Grand Rapids: Zondervan, 2013.

Thayer, Joseph Henry. Greek-English Lexicon of the New Testament. Grand Rapids, Michigan: Zondervan, 1975.

The Church of Pentecost, Pentecost Fire and Hour Report in December, 1974 annual report, COP Archives, Accra.

Vincent, Marvin R. Word Studies in the New Testament. Grand Rapids, Michigan: Zondervan Publications, 1969.

Wagenaar, Hinne. "Stop Harassing the Gentiles: The Importance of Acts 15 for African Theology", Journal African Christian Thought, Vol. 6, No. 1 (June 2003).

White, Peter and Cornelius J.P Niemandt. The Missional Role of the Holy Spirit: Ghanaian Pentecostals' View and Practice, 49(1), (2015). Accessed online on June 12, 2020, from http://dx.doi.org/10.4102/ ids.v49i1.1987.

White, P., Tella, F. \& Ampofo, M.D., "A missional study of the use of social media (Facebook) by some Ghanaian Pentecostal Pastors". KOERS - Bulletin for Christian Scholarship, 81.2(2016). Available at: http://dx.doi.org/10.19108/ koers.81.2.2250

White Peter and Assimeng, Abraham. Televangelism: A study of the 'Pentecost Hour' of the Church of Pentecost. HTS Teologiese Studies / Theological Studies. 72(2016). 10.4102/hts.v72i3.3337.

Williams, David J, Acts: Understanding the Bible Commentary Series. Michigan: Baker Publishing Group, 2011. 